\title{
PERBANDINGAN METODE KUADRAT TERKECIL DAN METODE BAYES PADA MODEL REGRESI LINIER BERGANDA YANG MENGANDUNG MULTIKOLINIERITAS
}

\author{
SISKA AUQINO, MAIYASTRI, RITA DIANA \\ Program Studi S1 Matematika, \\ Fakultas Matematika dan Ilmu Pengetahuan Alam, Universitas Andalas, \\ Kampus UNAND Limau Manis Padang, Indonesia. \\ email : sauqino16@gmail.com
}

Diterima 9 Maret 2019 Direvisi 7 April 2019 Dipublikasikan 7 Mei 2019

\begin{abstract}
Abstrak. Penelitian ini bertujuan untuk mengkaji perbandingan Metode Kuadrat Terkecil (MKT) dan metode Bayes pada model regresi linier berganda yang mengandung multikolinieritas. Pada regresi linier berganda, asumsi yang sering tidak terpenuhi yaitu tidak ada multikolinieritas di antara variabel prediktor. Adanya multikolinieritas menyebabkan estimasi MKT menjadi tidak efisien. Oleh karena itu diperlukan metode alternatif yang menghasilkan kesalahan estimasi yang lebih kecil. Data yang digunakan adalah data random dengan dua variabel prediktor yang dibangkitkan sehingga data memenuhi sifat model yang diteliti. Penelitian ini menunjukkan bahwa metode Bayes lebih baik dalam mengestimasi parameter regresi linier berganda dilihat dari nilai $M e a n$ Squared Error(MSE) yang lebih kecil dibandingkan dengan MKT.
\end{abstract}

Kata Kunci: Metode Kuadrat Terkecil, Metode Bayes, Multikolinieritas

\section{Pendahuluan}

Analisis regresi adalah suatu analisis yang bertujuan untuk mengetahui apakah ada hubungan ketergantungan secara statistik di antara dua variabel, yaitu variabel prediktor dan variabel respon. Terdapat dua jenis analisis regresi linier yaitu regresi linier sederhana dan regresi linier berganda. Analisis regresi linier berganda merupakan suatu analisis yang menentukan hubungan satu variabel respon dengan lebih dari satu variabel prediktor. Metode yang digunakan untuk mengestimasi parameter pada analisis regresi yaitu Metode Kuadrat Terkecil (MKT). Salah satu asumsi yang sering terlanggar pada regresi linier berganda, yaitu tidak ada multikolinieritas antar variabel prediktor. Adanya kasus multikolinieritas menyebabkan Standard Error (SE) dari parameter regresi membesar sehingga diperlukan metode alternatif dalam mengestimasi parameter regresi linier berganda.

Metode Bayes tidak sepenuhnya menggunakan informasi data sampel, tetapi juga memanfaatkan informasi awal (prior) sehingga memiliki kemampuan mengestimasi parameter lebih baik dibanding Metode Kuadrat Terkecil (MKT). Estimasi 
parameter dengan metode Bayes menghasilkan kesalahan estimasi yang relatif lebih kecil [7]. Pada penelitian ini akan dilakukan estimasi parameter dengan Metode Kuadrat Terkecil (MKT) dan metode Bayes pada model regresi linier berganda yang mengandung multikolinieritas menggunakan data simulasi dengan ukuran sampel yang berbeda. Estimasi model regresi linier berganda pada Metode Kuadrat Terkecil menggunakan software Minitab 17, sementara itu pada metode Bayes menggunakan software WinBUGS.

\section{Landasan Teori}

\subsection{Metode Kuadrat Terkecil}

Salah satu metode dalam mengestimasi parameter regresi linier berganda adalah Metode Kuadrat Terkecil (MKT). Secara umum, model regresi linier berganda yaitu

$$
Y_{i}=\beta_{0}+\beta_{1} X_{1 i}+\cdots+\beta_{j} X_{j i}+\varepsilon
$$

MKT bertujuan untuk meminimumkan Jumlah Kuadrat Galat (JKG). Estimasi parameter model regresi linier berganda dapat dihitung dengan :

$$
\hat{\beta}=\left(\mathbf{X}^{\prime} \mathbf{X}\right)^{-1}\left(\mathbf{X}^{\prime} \mathbf{Y}\right) .
$$

\section{Best Linear Unbiased Estimator (BLUE)}

Suatu estimator dari metode kuadrat terkecil adalah BLUE jika memenuhi sifatsifat [2] : (1) Linier, (2) Tak bias dan (3) Variansi minimum.

\subsection{Multikolinieritas}

Multikolinieritas diperkenalkan pertama kali oleh Ragnar Frisch pada tahun 1934 yang berarti adanya hubungan linier yang pasti atau tepat di antara beberapa atau semua variabel prediktor pada model regresi linier berganda [2].

\section{Konsekuensi Multikolinieritas}

Adanya multikolinieritas akan menimbulkan beberapa konsekuensi sebagai berikut [3] :

(1) Meskipun BLUE tetapi estimator parameter MKT memiliki variansi dan kovarian yang besar sehingga estimasi menjadi kurang akurat.

(2) Selang kepercayaan estimator parameter regresi menjadi lebar akibat konsekuensi (1).

(3) Statistik uji t dari satu atau lebih koefisien regresi akan cenderung tidak signifikan akibat konsekuensi (1).

(4) Walaupun statistik uji $t$ cenderung tidak signifikan, nilai model bisa bernilai tinggi. 


\section{Pendeteksian Multikolinieritas}

Multikolinieritas dapat dideteksi melalui Variance Inflation Factor (VIF). VIF dapat dihitung menggunakan [4] :

$$
V I F_{j}=\frac{1}{1-R_{k}^{2}}
$$

dimana $R_{k}^{2}$ adalah koefisien determinasi dari variabel $X_{j}$ sebagai variabel respon terhadap $(k-1)$ variabel prediktor lainnya. Apabila nilai VIF $>10$ maka terdapat kasus multikolinieritas antar variabel prediktor [4].

\subsection{Metode Bayes}

Metode Bayes diperkenalkan pertama kali oleh Reverend Thomas Bayes pada tahun 1763. Metode Bayes memandang semua parameter yang tidak diketahui sebagai peubah acak yang memiliki distribusi awal yang disebut distribusi prior [1]. Ada beberapa jenis distribusi prior dalam metode Bayes yaitu (1) Prior konjugat dan non konjugat dan (2) Prior informatif dan noninformatif. Distribusi prior konjugat merupakan distribusi prior yang ditentukan berdasarkan pada pola likelihood data.

\section{Distribusi Prior}

Distribusi prior pada penelitian ini yaitu prior konjugat. Berikut ini prior gabungan dari parameter regresi linier berganda :

$$
f(\beta, \tau)=\prod_{i=1}^{n}\left(\sqrt{\tau_{\beta_{j}}}\right) \exp \left[-\frac{\tau_{\beta_{j}}}{2}\left(\beta_{j}-\mu_{j}\right)^{2}\right] \times \tau^{a-1} \exp (-b \tau) .
$$

\section{Fungsi Likelihood}

Bentuk fungsi likelihood pada regresi linier berganda dengan data berdistribusi normal adalah sebagai berikut :

$$
f(\mathbf{Y} \mid \beta, \tau)=\tau^{n / 2} \exp \left[-\frac{\tau}{2}(\mathbf{Y}-\mathbf{X} \beta)^{\prime}(\mathbf{Y}-\mathbf{X} \beta)\right] .
$$

Distribusi posterior merupakan fungsi kepekatan peluang bersyarat yang digunakan untuk mengestimasi parameter yang tidak diketahui [5]. Distribusi posterior dari parameter $\theta$ dibentuk melalui perkalian distribusi prior dengan fungsi likelihood dari data pada variabel respon $\mathrm{Y}$, dengan bentuk sebagai berikut.

$$
f(\theta \mid \mathbf{Y})=\frac{f(\mathbf{Y} \mid \theta) f(\theta)}{f(\mathbf{Y})} .
$$

\section{Distribusi Posterior}

Berikut ini posterior gabungan dari parameter regresi linier berganda :

$$
\begin{aligned}
f(\beta, \tau \mid \mathbf{Y})= & \tau^{n / 2} \exp \left[-\frac{-\tau}{2}(\mathbf{Y}-\mathbf{X} \beta)^{\prime}(\mathbf{Y}-\mathbf{X} \beta)\right] \\
& \times \prod_{i=1}^{n}\left(\sqrt{\tau_{\beta_{j}}}\right) \exp \left[-\frac{\tau_{\beta_{j}}}{2}\left(\beta_{j}-\mu_{j}\right)^{2}\right] \times \tau^{a-1} \exp (-b \tau) .
\end{aligned}
$$


310 Siska Auqino dkk

\section{Markov Chain Monte Carlo}

Estimasi parameter menggunakan metode Bayes dapat dilakukan dengan Markov Chain Monte Carlo (MCMC). MCMC merupakan metode untuk membangkitkan sampel acak dari distribusi peluang dengan membentuk rantai Markov sesuai distribusi yang digunakan. Teknik MCMC digunakan pada model yang sangat rumit dan dapat mengestimasi distribusi posterior secara tepat. Salah satu algoritma yang dapat digunakan pada MCMC, yaitu algoritma Gibbs Sampling [6].

\section{Pembahasan}

\subsection{Pendeteksian Multikolinieritas}

Berdasarkan data yang dibangkitkan dengan jumlah sampel $n=20$, diperoleh nilai VIF sebesar 10,26 yang menunjukkan bahwa terdapat kasus multikolinieritas antar variabel $X_{1}$ dan $X_{2}$. Hubungan linier antar variabel $X_{1}$ dan $X_{2}$ dapat dilihat dari matrix plot pada Gambar 1.

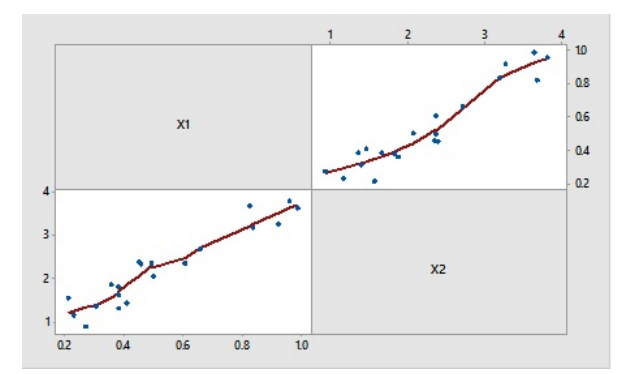

Gambar 1. Matrix Plot $X_{1}$ dan $X_{2}$

\subsection{Perbandingan Hasil Estimasi Parameter Regresi Linier Berganda}

Estimator Parameter

Tabel 1. Nilai Estimator Parameter

\begin{tabular}{|c|c|c|c|}
\hline $\mathrm{n}$ & Parameter & Estimator (MKT) & Estimator (Bayes) \\
\hline \multirow{3}{*}{20} & $\beta_{0}$ & 3,18 & 3,192 \\
\cline { 2 - 4 } & $\beta_{1}$ & 2,46 & 2,453 \\
\cline { 2 - 4 } & $\beta_{2}$ & 3,66 & 3,655 \\
\hline
\end{tabular}

Berdasarkan Tabel 1 diperoleh bahwa nilai estimator parameter regresi cenderung mendekati nilai awal yang sudah ditetapkan yaitu $\beta_{0}=2, \beta_{1}=3$, dan $\beta_{2}=4$ pada ukuran sampel $n=20$, hal yang sama juga ditunjukkan oleh ukuran 
sampel lainnya. Estimator parameter dengan MKT memiliki hasil yang relatif sama dengan Metode Bayes.

\section{Mean Squared Error Estimator Parameter}

Tabel 2. Nilai Mean Squared Error Estimator Parameter

\begin{tabular}{|c|c|c|c|}
\hline $\mathrm{n}$ & Parameter & MSE (MKT) & MSE (Bayes) \\
\hline \multirow{3}{*}{20} & $\beta_{0}$ & 3,11 & 2,17 \\
\hline & $\beta_{1}$ & 35,81 & 3,40 \\
\hline & $\beta_{2}$ & 2,91 & 0,96 \\
\hline \multirow{3}{*}{30} & $\beta_{0}$ & 1,50 & 0,73 \\
\hline & $\beta_{1}$ & 49,78 & 20,17 \\
\hline & $\beta_{2}$ & 3,68 & 2,06 \\
\hline \multirow{3}{*}{20} & $\beta_{0}$ & 2,25 & 1,77 \\
\hline & $\beta_{1}$ & 29,67 & 15,88 \\
\hline & $\beta_{2}$ & 3,06 & 2,24 \\
\hline \multirow{3}{*}{20} & $\beta_{0}$ & 0,29 & 0,32 \\
\hline & $\beta_{1}$ & 4,46 & 1,19 \\
\hline & $\beta_{2}$ & 0,40 & 0,32 \\
\hline \multirow{3}{*}{20} & $\beta_{0}$ & 0,23 & 0,29 \\
\hline & $\beta_{1}$ & 5,82 & 3,96 \\
\hline & $\beta_{2}$ & 5,79 & 3,96 \\
\hline \multirow{3}{*}{20} & $\beta_{0}$ & 0,15 & 0,22 \\
\hline & $\beta_{1}$ & 1,37 & 0,88 \\
\hline & $\beta_{2}$ & 0,14 & 0,19 \\
\hline
\end{tabular}

Berdasarkan Tabel 2 dapat diketahui bahwa nilai MSE estimator parameter regresi linier berganda dengan MKT dan metode Bayes cenderung mengalami penurunan seiring kenaikan ukuran sampel. Hasil nilai MSE estimator parameter regresi untuk setiap ukuran sampel pada metode Bayes lebih kecil dibandingkan dengan hasil dari MKT. Hal ini menunjukkan bahwa metode Bayes memiliki kemampuan yang lebih baik dalam mengestimasi parameter model regresi linier berganda karena kesalahan estimasi yang lebih kecil dibandingkan dengan MKT.

\section{Kesimpulan}

Berdasarkan hasil pembahasan yang telah dilakukan tentang perbandingan Metode Kuadrat Terkecil dan Metode Bayes pada model regresi linier berganda yang mengandung multikolinieritas didapatkan kesimpulan bahwa pada simulasi data yang dilakukan dengan ukuran sampel $n=20,30,60,100,200$ dan 500, metode Bayes lebih baik dalam mengestimasi karena memiliki nilai Mean Squared Error (MSE) dari estimator parameter regresi lebih kecil dibandingkan dengan Metode Kuadrat Terkecil. Metode Bayes dapat mengatasi multikolinieritas pada model regresi linier 
312 Siska Auqino dkk

berganda dengan ukuran sampel $n=20$ karena diperoleh hasil nilai VIF kurang dari 10.

\section{Daftar Pustaka}

[1] Bolstad, W.M., 2007, Introduction to Bayesian Statistical, Second Edition, Jhon Wiley Sons, America

[2] Gujarati, D., 1995, Ekonometrika Dasar, Erlangga, Jakarta

[3] Gujarati, D., 2011,Econometrics by Example, Palgrave Macmillan, New York

[4] Montgomery, D.C. and Peck, E.A., 1992, Introduction to Linear Regression Analysis, Second Edition, Jhon Wiley Sons, America

[5] Mukhopadhyay, N., 2000, Probability and Statistical Inference, Marcel Dekker, New York

[6] Ntzoufras, I., 2009, Bayesian Modelling using WinBUGS, Jhon Wiley Sons, California

[7] Pereira, F., 1999, Practical Modern Bayesian Statistics In Acturial Science, General Insurance Convention 